\title{
The Impact of Raising Awareness of the Speech Act on Speaking Ability across Gender and Proficiency Level
}

\author{
El impacto de aumentar la conciencia del acto de habla en la habilidad \\ de speaking a través del género y el nivel de suficiencia
}

\section{Kobra Ghayebi ${ }^{1}$ \\ Parisa Farrokh ${ }^{2}$}

\begin{abstract}
The present study intended to investigate the possible effects of speech acts strategies on Iranian beginner and intermediate EFL learners' speaking ability. The first step in conducting this research was the administration of QPT as the homogenizing tool. It was administered to 180 beginners and intermediate EFL learners. After analyzing the results, 80 males and females as starters and 80 males and females as intermediate subjects were chosen. Then, the beginner and intermediate EFL learners were randomly divided into control and experimental groups (including 40 beginner male and 40 female EFL learners in each class). Next, a pretest of speaking was administered to all the participants and the experimental groups received speech act role play as treatment. However, the researcher did not use any treatment of speech acts in control groups. After ten sessions, the posttest was administered to all participants. The findings suggested that awareness raising on speech acts resulted in a better speaking
\end{abstract}

Kobra Ghayebi is an MA student in TEFL. She studies at the Department of English Language, Lahijan Branch, Islamic Azad University, Lahijan, Iran. She has received her BA from Islamic Azad University, Rasht Branch. She teaches English in different institutes. She is interested in pragmatics, discourse and psycholinguistics.

kobra.ghayebi@gmail.com

ORCID: https://orcid.org/0000-0001-5902-7257

2 Parisa Farrokh is currently an assistant professor at the Department of English Language, Lahijan Branch, Islamic Azad University, Lahijan, Iran. She has published and presented some articles in different national and international journals and conferences. Her areas of interest include pragmatics, discourse and psycholinguistics.

farrokh_p@yahoo.com

ORCID: https://orcid.org/0000-0002-6454-9305

Received: March 27st, 2020. Accepted: July 21st, 2020.

This article is licensed under a Creative Commons Attribution-Non-Commercial-No-Derivatives 4.0 International License. License Deed can be consulted at https://creativecommons.org/licenses/by-ncnd $/ 4.0$. 
ability as compared to the simply traditional teaching of speaking for Iranian intermediate and beginner EFL learners. Additionally, intermediate EFL learners' achievement in speaking was not in line with the beginner EFL learners' achievement in the corresponding group. Finally, it was found that gender does not interact with awareness raising on speech acts in such a way as to produce a statistically significant effect on the beginner and intermediate EFL learners' speaking ability.

Keywords: English language learners, pragmatics, speaking skill, proficiency level, speech act

\section{Resumen}

Este estudio busca investigar los posibles efectos de las estrategias de acto de habla en la habilidad de speaking en estudiantes iraníes de nivel principiante e intermedio. El primer paso en el estudio fue la toma de un examen QPT como herramienta de homologación a 180 estudiantes de inglés de nivel principiante e intermedio. Con el análisis de estos puntajes, 80 estudiantes hombres y mujeres se escogieron para cada nivel. Estos estudiantes luego se dividieron en dos grupos, uno de control y otro experimental (40 estudiantes de cada nivel en cada grupo). Luego, un pre-test de speaking se administró a todos los participantes; solo los grupos experimentales recibieron un tratamiento de actos de habla de juego de roles. Luego de diez sesiones, un pos-test se administró a todos los participantes. Los hallazgos sugieren que el aumento de consciencia del acto de habla es el resultado de una mejor habilidad de speaking comparada simplemente con una enseñanza tradicional de esta habilidad a los estudiantes de ambos niveles. Adicionalmente, los estudiantes de nivel intermedio no están en línea con los del nivel principiante. Finalmente, no se encontró que la categoría género interactúe con el aumento de consciencia del acto de habla a tal punto que produzca un efecto significativo estadístico en los estudiantes de ambos niveles.

Palabras clave: aprendices de inglés, pragmática, habilidad de habla, nivel de suficiencia, acto de habla

\section{Introduction}

One of the salient objectives in language classrooms is to enable learners to communicate in the target language. This aim is not fully achieved unless the sociocultural context of the second language is also taken into consideration, because learning isolated words and phrases will never serve the communicative purpose (Cohen, 1996).

More recently, in EFL contexts, learners are required to utilize the English language for their communicative needs to do business, read scientific articles, and use Information and Communications Technology (ICT) worldwide and so on. They also learn English and make use of it to interact with speakers of English from different cultures. As such, the English language plays a highly important role in intercultural interactions as a communication tool and calls into attention the issue of proper and appropriate intercultural understanding of speech or more importantly, meaning in interaction between speakers (Al-Zubeiry, 2013; Rashidi \& Ramezani, 2013). 
However, cross-cultural misunderstanding occurs in the communication between individuals from different socio-cultural backgrounds and it is one of the difficulties that EFL speakers face in the act of communication (Rashidi \& Ramezani, 2013). It is claimed that the most important cause of intercultural misunderstanding is related to pragmatic failure in using the appropriate speech (Farahian, Rezaee, \& Gholami, 2012).

Therefore, in order to avoid intercultural misunderstandings and the resultant pragmatic failure, EFL learners' pragmatic knowledge as the core construct of communicative competence should be developed. This can result in more effective and successful intercultural communication (Nguyen, 2011). In this regard, the aim of this study is to investigate the effect of speech act instruction on the speaking ability of Iranian EFL learners across gender and proficiency levels. Therefore, the following research questions were put forth:

RQ1. Is there any statistically significant difference between the beginner EFL learners who receive awareness raising on speech acts and those who receive traditional instruction in terms of their L2 speaking ability?

RQ2. Is there any statistically significant difference between the intermediate EFL learners who receive awareness raising on speech acts and those who receive traditional instruction in terms of their L2 speaking ability?

RQ3. Does gender interact with awareness raising on speech acts in such a way as to produce a statistically significant effect on the beginner EFL learners' speaking ability?

RQ4. Does gender interact with awareness raising on speech acts in such a way as to produce a statistically significant effect on the intermediate EFL learners' speaking ability? To fulfill the aim of the study in a practical manner through the above mentioned research questions, the following null hypotheses have been considered:

H01. There is not a statistically significant difference between the beginner EFL learners who receive awareness raising on speech acts and those who receive traditional instruction in terms of their L2 speaking ability.

H02. There is not a statistically significant difference between the intermediate EFL learners who receive awareness raising on speech acts and those who receive traditional instruction in terms of their L2 speaking ability.

H03. Gender does not interact with awareness raising on speech acts in such a way as to produce a statistically significant effect on the beginner EFL learners' speaking ability.

H04. Gender does not interact with awareness raising on speech acts in such a way as to produce a statistically significant effect on the intermediate EFL learners' speaking ability. 
Kobra Ghayebi

Parisa Farrokh

\section{Literature Review}

EFL or ESL learners can develop their pragmatics in two ways: exposure to input and production of output through classroom use of the target language, or from a planned pedagogical intervention directed toward the acquisition of pragmatics (Kasper \& Dahl, 1991). Classroom languages have been considered poor environments compared to outside environments. Because of this limitation vast demands are imposed on instruction that most likely cannot be attained through the traditional classroom format. Foreign-language learners have limited exposure to the target language compared to second-language learners.

In an EFL setting, the language of classroom activities is decontextualized which does not expose learners to the types of sociolinguistic input that facilitates pragmatic competence acquisition. In addition, research has shown that many aspects of pragmatic competence cannot be acquired without a focus on pragmatics instruction (Kasper, 2008).

Genç and Tekyıldız (2009) investigated the relationship between learners' use of speech acts and the region of their residence (urban or rural), focusing on the use of refusal strategies by Turkish EFL students. A discourse completion questionnaire (DCQ) was used to detect possible differences between the preferred refusal strategies of Turkish EFL students and those of native English speakers (NESs) in relation to rural or urban areas of residence of the participants. Both groups, the 101 Turkish EFL students and 50 NESs were divided into two groups according to their geographical origins: rural or urban. The results showed that the four groups produced similar refusal strategies in general. Furthermore, the interlocutor's status was found to have an important effect on the strategy preferences of the speakers. Similarly, most of the participants generally used indirect strategies so as to be politer. However, Turkish EFL students frequently chose direct strategies while using the speech acts of refusal, unlike NESs who were mostly indirect while refusing.

Bardovi-Harlig (2001) proposed the necessity of instruction in pragmatics by documenting that foreign language learners who do not receive instruction in pragmatics differ significantly from native speakers in their pragmatic production and comprehension in the target language. Improving pragmatics in the classroom develops the learners' competence in a foreign language setting. Additionally, continued practice leads to faster and more efficient acquisition of sociopragmatic and pragma-linguistic knowledge in the learners' interlanguage system.

Ishihara (2007) studied a one-month online course on speech acts that was designed to instill a sense of appropriate language use in the university students of the Japanese language who volunteered to participate. The data consisted of journal entries produced by the students as they completed each of the five speech act units. The comments from students confirmed that the explicit teaching of pragmatic features and the cultural ideologies that underlie them did result in a heightened awareness. In addition, practicing the language 
forms in varying contexts generated greater competence. Of particular note to the present essay is the finding that the students taking the online course felt that the teaching of speech acts should be integrated into the curriculum.

In a study conducted by Félix Brasdefer (2008), it was cleared that speech acts are highly complex and also highly sensitive to a number of social variables including gender, age, power or social distance. In request situations, refusals, especially for nonnative speakers for a given language, are extremely complex in that they "require not only long sequences of negotiation and cooperative achievements" (p. 196), but will also need to incorporate face-saving strategies that will rebalance the noncompliant component of the speech act.

In another related study, Morkus (2014) investigated differences between Egyptian speakers and American speakers in the production of refusals. In order to determine certain discourse-level patterns indigenous patterns peculiar to refusal acts, the researcher obtained the data of the study through role-plays. The participants in the study were 10 American and 10 Egyptian native speakers. The findings of the research demonstrated that Egyptian speakers used more words than American speakers did in their realization of refusals. Another distinctive difference was that American speakers were more direct than Egyptian speakers when performing speech acts of refusal.

Aforementioned issues have shown the main goal of the current study, i.e., the effect of speech act on EFL learners' speaking ability. As a matter of fact, many learners may not be aware of socially and culturally appropriate forms which may lead to communication breakdown or communication conflict. Therefore, it seems necessary to appreciate a theory which accounts for language use among which speech act theory plays a crucial role. This is because speech act theory includes all the acts we do while speaking; also, its main contribution is developing communicative competence.

\section{Research Methodology}

\section{Research Design}

The present study employed a true experimental design which required randomization,

administration of a QPT (Quick Placement Test) and an interview of 180 Iranian EFL learners. Figure 1 illustrates the steps taken in this study.

\section{Participants and Sampling}

A community sample of 180 EFL learners participated in this study, comprising 80 males and 80 females aged from 15 to 19. They were all EFL learners studying in a private 

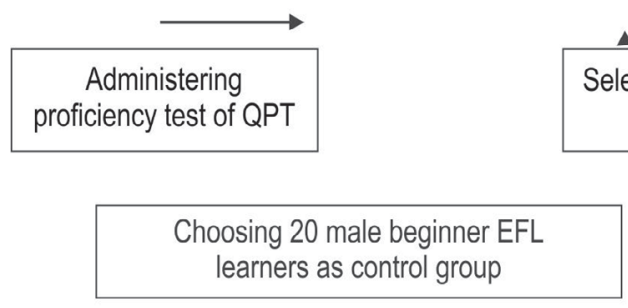
Choosing 20 female beginner EFL learners as control group
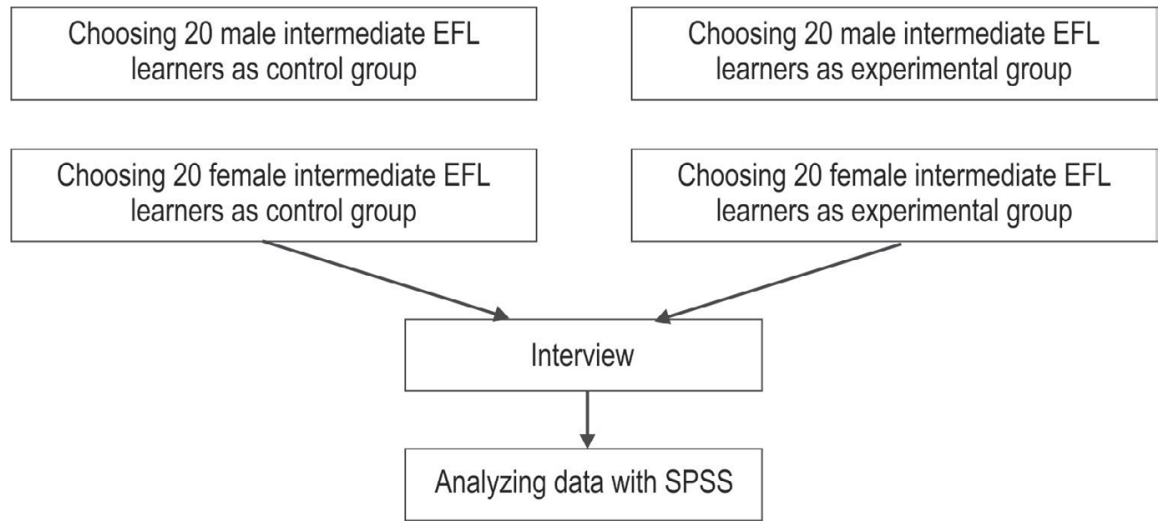

Figure 1. The Design of the Study
Choosing 20 male beginner EFL learners as experimental group

Choosing 20 female beginner EFL learners as experimental group

Choosing 20 male intermediate EFL learners as experimental group Ceosing 20 female intermediate EFL

language institute in Rasht, Iran. Out of this population, 160 learners were selected based on a Quick Placement Test (QPT). In this study, gender and proficiency level were considered as effective factors. The sample comprised of two different levels- starter and intermediate, and participants were divided into control and experimental groups.

\section{Instruments}

As it was mentioned before, the first step in conducting this research was the administration of QPT as the homogenizing tool. It was administered to 120 beginners and intermediate EFL learners. After analyzing the results, 40 male and female starter and 40 male and female intermediate subjects were chosen. Then, the pretest was administered. It 
was an interview which consisted of descriptive questions based on different topics such as: personal information and family, man and society, our environment, school, work, life-style, free-time and entertainment, travelling, science and technology. The reliability of the QPT and interview were also checked through the pilot study on 15 subjects. Cronbach's alpha statistics were computed. Cronbach's alpha for QPT was $(\alpha$ QPT $=.77)$ and for the interview was $(\alpha$ interview $=.81)$, which are both considerably higher than the minimum required value of $(\alpha=.70)$. After ten sessions of speech act instruction to experimental groups, the posttest was administered to measure the learners' progress in all groups. The pretest and posttest questions were the same.

\section{Procedure}

The Quick Placement Test (QPT) was administered to 180 EFL learners in order to select a homogeneous sample. This test was conducted to homogenize the participants based on their level of proficiency. Then, 80 male and female learners whose scores were in the range of 18- 27 were chosen as beginner and 80 male and female learners whose scores were in the range of 37-47 were chosen as intermediate. An interview was used to measure the learners' speaking ability. Later, two raters assessed the answers. To make sure of the consistency of the scores, inter-rater reliability was calculated. The score of each participant then was the average of the scores given by the two raters. Next, experimental groups received speech act role play as treatment. For each session before speaking, the teacher taught them how to response in different situations. However, the researcher did not use any treatment of speech acts in control groups.

After ten sessions, the posttest of speech acts was administered to all participants. To measure the learners' improvement, an interview like the pretest was conducted. The responses were rated by the same raters of the pretest phase. Inter-rater reliability was calculated again, and the average of the scores given by the two raters was considered as the final score of each participant.

Through the Univariate procedure, a two-way analysis of variance was run on the results of the pretests of speaking to examine their prior knowledge regarding speaking ability. To answer the research questions (1 to 4 ), the Univariate analysis of variance was run on the results of the posttests of speaking. It provided analysis of variance for the single dependent variable (speaking ability) by three factors (types of treatment with two levels, gender, and level of foreign language proficiency).

Before running the Univariate procedure, the main assumptions of the parametric tests were examined and it was established that the data comprised a random sample from a normal population; in the population, all cell variances were the same and the data were symmetric. The homogeneity of variances tests was also checked. 
Kobra Ghayebi

Parisa Farrokh

\section{Findings}

At the beginning of the study, all the participants took part in pretests. The purpose was to set up a baseline from which gains on the posttest could be compared. Descriptive statistics including means and standard deviations, 95\% confidence interval for the mean, and the trimmed means were computed for the results of the pretest and posttest scores of speaking for the groups. The results are presented in Table 1.

Table 1. Descriptive Statistics for the Pre and Post-Test Scores off Speaking

\begin{tabular}{|c|c|c|c|c|c|c|c|c|}
\hline \multirow{2}{*}{$\begin{array}{c}\text { Level of } \\
\text { proficiency }\end{array}$} & \multirow{2}{*}{$\begin{array}{l}\text { Study } \\
\text { groups }\end{array}$} & \multirow{2}{*}{\multicolumn{2}{|c|}{ Gender }} & \multirow{2}{*}{ Mean } & \multicolumn{2}{|c|}{$\begin{array}{l}95 \% \text { Confidence } \\
\text { Interval for Mean }\end{array}$} & \multirow{2}{*}{$\begin{array}{c}5 \% \text { Trimmed } \\
\text { Mean }\end{array}$} & \multirow{2}{*}{$\mathrm{SD}$} \\
\hline & & & & & Lower & Upper & & \\
\hline \multirow{8}{*}{ intermediate } & \multirow{4}{*}{ Control } & \multirow{2}{*}{ female } & Pretest & 13.97 & 12.93 & 15.01 & 13.97 & 2.21 \\
\hline & & & Posttest & 14.17 & 13.04 & 15.30 & 14.13 & 2.40 \\
\hline & & \multirow{2}{*}{ male } & Pretest & 14.70 & 13.59 & 15.80 & 14.72 & 2.35 \\
\hline & & & Posttest & 14.72 & 13.72 & 15.72 & 14.72 & 2.13 \\
\hline & \multirow{4}{*}{ Experimental } & \multirow{2}{*}{ female } & Pretest & 14.35 & 13.37 & 15.32 & 14.38 & 2.09 \\
\hline & & & Posttest & 17.02 & 16.42 & 17.62 & 17.00 & 1.28 \\
\hline & & \multirow{2}{*}{ male } & Pretest & 13.65 & 12.74 & 14.55 & 13.66 & 1.93 \\
\hline & & & Posttest & 16.60 & 16.01 & 17.18 & 16.66 & 1.24 \\
\hline \multirow{8}{*}{ Beginner } & \multirow{4}{*}{ Control } & \multirow{2}{*}{ female } & Pretest & 15.07 & 14.28 & 15.86 & 15.05 & 1.69 \\
\hline & & & Posttest & 15.10 & 14.29 & 15.90 & 15.08 & 1.72 \\
\hline & & \multirow{2}{*}{ male } & Pretest & 14.27 & 13.41 & 15.13 & 14.27 & 1.83 \\
\hline & & & Posttest & 14.42 & 13.48 & 15.36 & 14.41 & 2.00 \\
\hline & \multirow{4}{*}{ Experimental } & \multirow{2}{*}{ female } & Pretest & 14.67 & 13.58 & 15.76 & 14.72 & 2.32 \\
\hline & & & Posttest & 16.42 & 15.55 & 17.29 & 16.52 & 1.85 \\
\hline & & \multirow{2}{*}{ male } & Pretest & 13.90 & 12.94 & 14.85 & 13.80 & 2.03 \\
\hline & & & Posttest & 16.50 & 15.85 & 17.14 & 16.52 & 1.37 \\
\hline
\end{tabular}

For the students who were at intermediate level, for the speaking test that was administered at the beginning of the study, the mean scores for the control and the experimental groups were $\left(M_{\text {Co. Internediate female }}=13.97\right),\left(M_{\text {Co. Intermediate male }}=14.70\right),\left(M_{\text {Ex. Intermediate female }}=14.35\right),\left(M_{E x . \text { Intermediate male }}=\right.$ 13.65), respectively. Furthermore, for the speaking test that was administered at the end of the study, the mean scores for the control and the experimental groups were $\left(M_{\text {Co. Intermediatefemale }}=14.17\right)$, $\left(M_{\text {Co. Intermediate male }}=14.72\right),\left(M_{\text {Ex. Intermediate female }}=17.02\right),\left(M_{\text {Ex. Intermediate male }}=16.60\right)$, respectively. 
For the students who were beginner language learners, for the speaking test that was administered at the beginning of the study, the mean scores for the control and the experimental groups were $\left(M_{\text {Co. Beginner female }}=15.07\right),\left(M_{\text {Co. Beginner male }}=14.27\right),\left(M_{\text {Ex. Beginner female }}=\right.$ 14.67), $\left(M_{\text {Ex. Beginner male }}=13.90\right)$, respectively. Furthermore, for the speaking test that was administered at the end of the study, the mean scores for the control and the experimental groups were $\left(M_{\text {Co. Beginner female }}=15.10\right),\left(M_{\text {Co. Beginner male }}=14.42\right),\left(M_{\text {Ex. Beginner female }}=16.42\right),\left(M_{\text {Ex. Beginner }}\right.$ male $=16.50)$, respectively.

The descriptive table showed that there were simply minor differences among the means of the groups at the beginning of the study. However, when it comes to the posttest scores, the control groups that were treated traditionally had the lowest mean scores in both intermediate and beginner groups. On the other hand, the experimental groups who had received instruction on speech acts performed better than the control groups on the posttest of speaking in both intermediate and beginner groups.

In order to examine if the mean differences among the groups were statistically significant for the speaking tests, a Univariate analysis of variance was run on the results of the pre and posttests. Before running the analysis, the homogeneity of the variances was checked out through computing Levene's test.

Table 2. Levene's Test for Examining the Homogeneity of Variances (Pre and Posttest Scores)

\begin{tabular}{|l|c|c|c|c|}
\hline & F & df1 & df2 & Sig. \\
\hline pretest scores & 1.283 & 7 & 152 & .262 \\
\hline posttest scores & 1.083 & 7 & 152 & .377 \\
\hline
\end{tabular}

The findings of Levene's test statistics showed that for the speaking test, the group variances were similar in pre- test scores $\left(\mathrm{F}_{\text {pre- test speaking }} 7,152=1.283 ; \mathrm{P}_{\text {pre- test speaking }(262)}\right.$ $\geq .05)$. The findings also showed that the group variances were similar in post- test scores (F

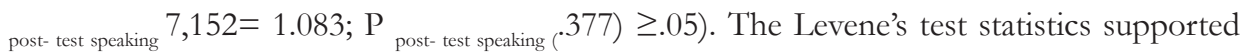
the hypothesis that the group variances were the same for the pre and posttest scores and thus the first assumption of the parametric tests that was homogeneity of the variances was established.

When it comes to the normality assumption, the results of the skewness and kurtosis analyses were used to examine the normality assumption. The results of the skewness analysis are presented in Table 3. 
Table 3. Skeenness and Kurtosis Analyses for the Pre and Post-Test Scores

\begin{tabular}{|c|c|c|c|c|c|c|}
\hline $\begin{array}{c}\text { Level of } \\
\text { proficiency }\end{array}$ & Study groups & Gender & & $\begin{array}{c}\mathbf{N} \\
\text { Valid }\end{array}$ & Skewness & Kurtosis \\
\hline \multirow{8}{*}{ Intermediate } & \multirow{4}{*}{ Control } & \multirow{2}{*}{ Female } & Pretest & 20 & .017 & -1.348 \\
\hline & & & Posttest & 20 & .107 & -1.491 \\
\hline & & \multirow{2}{*}{ Male } & Pretest & 20 & -.030 & -1.417 \\
\hline & & & Posttest & 20 & .112 & -1.433 \\
\hline & \multirow{4}{*}{ Experimental } & \multirow{2}{*}{ Female } & Pretest & 20 & -.212 & -1.023 \\
\hline & & & Posttest & 20 & .230 & -.870 \\
\hline & & \multirow{2}{*}{ Male } & Pretest & 20 & .087 & -1.213 \\
\hline & & & Posttest & 20 & -.529 & .487 \\
\hline \multirow{8}{*}{ Beginner } & \multirow{4}{*}{ Control } & \multirow{2}{*}{ Female } & Pretest & 20 & .316 & -.563 \\
\hline & & & Posttest & 20 & .407 & -.112 \\
\hline & & \multirow{2}{*}{ Male } & Pretest & 20 & .068 & -.850 \\
\hline & & & Posttest & 20 & .024 & -.707 \\
\hline & \multirow{4}{*}{ Experimental } & \multirow{2}{*}{ Female } & Pretest & 20 & -.399 & -1.039 \\
\hline & & & Posttest & 20 & -.483 & .023 \\
\hline & & \multirow{2}{*}{ Male } & Pretest & 20 & .508 & -.395 \\
\hline & & & Posttest & 20 & .168 & .234 \\
\hline
\end{tabular}

As it was shown in Table 3, the values of the skewness and kurtosis were all within the range of \pm 2 , supporting that the distributions were all normal. In addition, $50 \%$ of the trimmed means presented in Table 4 were within the range of 95\% Confidence Interval for mean for the lower and upper bounds. Therefore, the normality of the distributions was also confirmed.

After establishing the main assumptions of the parametric tests, Univariate analysis of variance (UNIANOVA) was run on the results of the pretest for the control and experimental groups at each level of language proficiency. It was run to see if there were any statistically significant differences among the groups in terms of their speaking skill before introducing the specific treatment. The findings of the UNIANOVA test are presented in Table 4. 
The Impact of Raising Awareness of the Speech Act on Speaking Ability across Gender and Proficiency Level

Table 4. Tests of Between Subjects Effects for the Pretest Scores of Speaking

\begin{tabular}{|c|c|c|c|c|c|c|c|}
\hline \multicolumn{8}{|c|}{ Dependent Variable: Pretest scores } \\
\hline $\begin{array}{l}\text { Level of } \\
\text { proficiency }\end{array}$ & Source & $\begin{array}{l}\text { Type III } \\
\text { Sum of } \\
\text { Squares }\end{array}$ & df & $\begin{array}{l}\text { Mean } \\
\text { Square }\end{array}$ & F & Sig. & $\begin{array}{c}\text { Partial } \\
\text { Eta } \\
\text { Squared }\end{array}$ \\
\hline \multirow{3}{*}{ Intermediate } & Study groups & 2.278 & 1 & 2.278 & .491 & .486 & .006 \\
\hline & Gender & .003 & 1 & .003 & .001 & .979 & .000 \\
\hline & Study groups * gender & 10.153 & 1 & 10.153 & 2.189 & 143 & .028 \\
\hline \multirow[t]{3}{*}{ Beginner } & Study groups & 3.003 & 1 & 3.003 & .759 & .386 & .010 \\
\hline & Gender & 12.403 & 1 & 12.403 & 3.134 & .081. & .040 \\
\hline & Study groups $*$ gender & .003 & 1 & .003 & .001 & .978 & .000 \\
\hline
\end{tabular}

The significance values of the $\mathrm{F}$ test in the UNIANOVA Table were greater than (.05) for the pretests of speaking for both intermediate and beginner groups. Thus, the average assessment scores for the pretests were equal across the control and experimental groups at the beginning of the study $\left(\mathrm{F}_{\text {speaking intermediate }}=.491, \mathrm{p}=.486>.05\right)$ and $\left(\mathrm{F}_{\text {speaking beginner }}=\right.$ $.759, \mathrm{p}=.386>.05)$. Moreover, the average assessment scores for the pretests were equal across the female and male participants in both the control and experimental groups at the beginning of the study $\left(\mathrm{F}_{\text {speaking intermediate (gender effect) }}=.001, \mathrm{p}=.979>.05\right)$ and $\left(\mathrm{F}_{\text {speaking beginner (gender }}\right.$ effect) $=3.134, \mathrm{p}=.081>.05)$.

Besides, the interaction effect of study groups and gender also were not statistically significant, $\left(\mathrm{F}_{\text {speaking intermediate (Study groups } *_{\text {gender }}}=2.189, \mathrm{p}=.143>.05\right)$ and $(\mathrm{F}$ speaking beginner (Study groups * gender) $=.001, \mathrm{p}=.978>.05)$ suggesting that there were not any statistically significant differences among the groups at the beginning of the study in terms of their speaking ability. The following figures depict the groups' performance on pre-test of speaking.

As it was depicted in Figure 2, the control and experimental groups' performances in pretest of speaking were approximately the same at the beginning of the study for the female and male intermediate EFL learners. The following figure makes a comparison among female and male beginner EFL learners who were in the control and experimental groups in terms of their pretest scores.

Figure 3 revealed that the groups did not differ with regard to their performance on pretest of speaking. The Univariate procedure was run on the results of the posttests to model the values of speaking tests based on their relationships to categorical predictors (i.e., gender and types of treatment). First, comparisons were made among beginner male 


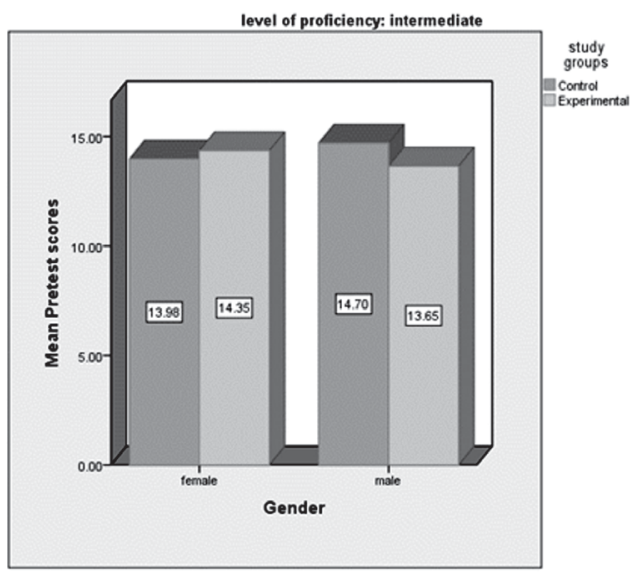

Figure 2. Experimental and Control Groups' Performance on Pretest of Speaking (Intermediate EFL Learners)

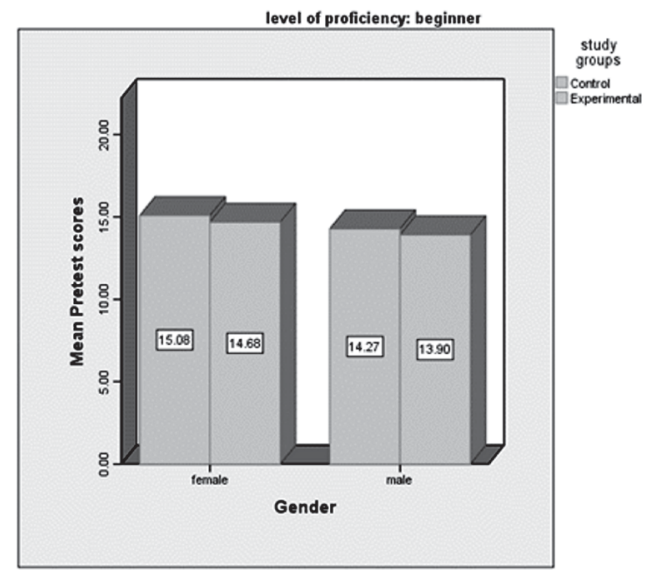

Figure 3. Experimental and Control Groups' Performance on Pretest of Speaking (Beginner EFL Learners)

and female EFL learners in the control group who received placebos and the experimental groups who received explicit instruction on speech acts. The results are given in Table 5 .

Given that the main effects of types of instruction (with and without awareness raising on speech acts) were significant for the beginner groups, the main effects were also examined in pairwise comparisons (See Table 5). In other words, significant differences were found 
Table 5. Univariate Test Results for the Speaking Test (Beginner)

\begin{tabular}{|c|c|c|c|c|c|c|c|}
\hline \multicolumn{8}{|c|}{ Tests of Between-Subjects Effects } \\
\hline \multicolumn{8}{|c|}{ Dependent Variable: Post test scores } \\
\hline $\begin{array}{l}\text { Level of } \\
\text { proficiency }\end{array}$ & Source & $\begin{array}{l}\text { Type III } \\
\text { Sum of } \\
\text { Squares }\end{array}$ & df & $\begin{array}{l}\text { Mean } \\
\text { Square }\end{array}$ & $\mathbf{F}$ & Sig. & $\begin{array}{c}\text { Partial } \\
\text { Eta } \\
\text { Squared }\end{array}$ \\
\hline \multirow{3}{*}{ Beginner } & Study groups ${ }^{a}$ & 57.800 & 1 & 57.800 & 18.767 & .000 & .198 \\
\hline & Gender & 1.800 & 1 & 1.800 & .584 & .447 & .008 \\
\hline & Study groups* gender & 2.813 & 1 & 2.813 & .913 & .342 & .012 \\
\hline
\end{tabular}

a. R Squared $=.211$ (Adjusted R Squared $=.179)$

on the dependent variable that comprised speaking scores for the control and experimental groups for the participants who were at beginner level $\left(\mathrm{F}_{\text {study groups (beginners) }}=18.767 ; \mathrm{p}=.000\right.$ $<.05)$. However, there were no statistically significant differences between beginner male and female EFL learners who were treated with speech acts in terms of their speaking skill at the end of the study $\left(\mathrm{F}_{\text {gender (beginners) }}=.584 ; \mathrm{P}=.447>.05\right)$. Moreover, the interaction effect of types of treatment and gender was not statistically significant ( $\mathrm{F}$ study groups * gender (beginners) $=.913 \mathrm{P}=.342>.05)$. Figure 4 depicts the beginner EFL learners' performance on posttest of speaking.

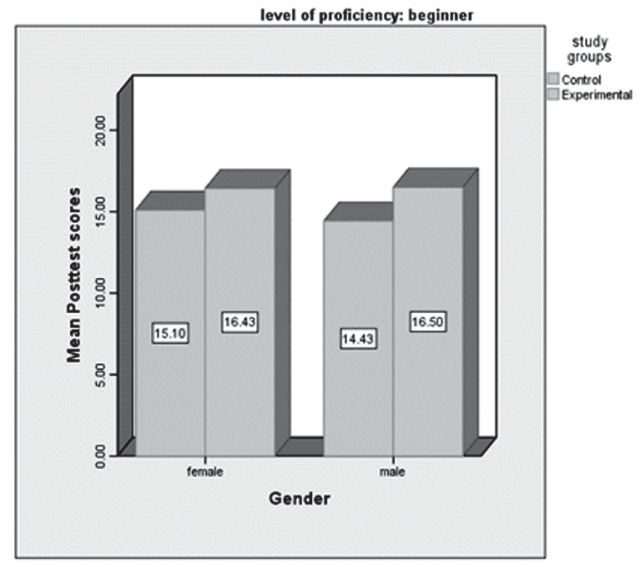

Figure 4. Experimental and Control Groups' Performance on Pretest of Speaking (Beginner EFL Learners) 
The next Univariate test was run on the results of the posttests to make comparisons among intermediate male and female EFL learners in the control groups who received placebos and the experimental groups who received awareness raising on speech acts. The results are given in Table 6.

Table 6. Univariate Test Results for the Speaking Test (Intermediate)

\begin{tabular}{|c|c|c|c|c|c|c|c|}
\hline \multicolumn{8}{|c|}{ Tests of Between-Subjects Effects } \\
\hline \multicolumn{8}{|c|}{ Dependent Variable: Post test scores } \\
\hline $\begin{array}{c}\text { Level of } \\
\text { proficiency }\end{array}$ & Source & $\begin{array}{l}\text { Type III } \\
\text { Sum of } \\
\text { Squares }\end{array}$ & df & $\begin{array}{l}\text { Mean } \\
\text { Square }\end{array}$ & $\mathbf{F}$ & Sig. & $\begin{array}{l}\text { Partial Eta } \\
\text { Squared }\end{array}$ \\
\hline \multirow{3}{*}{ Intermediate } & Study groups a & 111.628 & 1 & 111.628 & 33.022 & .000 & .303 \\
\hline & Gender & .078 & 1 & .078 & .023 & .880 & .000 \\
\hline & Study groups $*$ gender & 4.753 & 1 & 4.753 & 1.406 & .239 & .018 \\
\hline
\end{tabular}

a. R Squared $=.312($ Adjusted R Squared $=.285)$

As it was shown in Table 6, the main effects of types of instruction (with and without awareness raising on speech acts) were also significant for the intermediate groups and significant differences were reported regarding the speaking scores for the control and experimental groups ( $\left.\mathrm{F}_{\text {study groups (intermediate) }}=33.022 ; \mathrm{p}=.000<.05\right)$. Nevertheless, no statistically significant difference was found between intermediate male and female EFL learners who enjoyed awareness raising on speech acts in terms of their speaking skill at the end of the study $\left(\mathrm{F}_{\text {gender (intermediate) }}=.023 ; \mathrm{P}=.880>.05\right)$. Besides, the interaction effect of types of treatment and gender was not statistically significant $\left(\mathrm{F}_{\text {study groups* }{ }^{*} \text { gender (intermediate }}=1.406 ; \mathrm{P}=.239\right.$ $>$.05). Figure 5 depicts the intermediate EFL learners' performance on posttest of speaking.

Pairwise comparisons were also made for the posttest scores of speaking for the students who were treated traditionally and those who received instruction on speech acts at both 106 intermediate and beginner levels. The results of the comparisons for the intermediate group are presented in table 7.

Table 7 made pairwise comparisons between the control and experimental groups for the intermediate language learners in their posttest of speaking. For the speaking test that was administered at the end of the study, the mean difference between pre and posttests that was reported for the experimental group was higher than that compared to the mean difference for the control (mean difference ${ }_{\text {control group }}=.112$; mean difference experimental group $=2.812$ ). While 


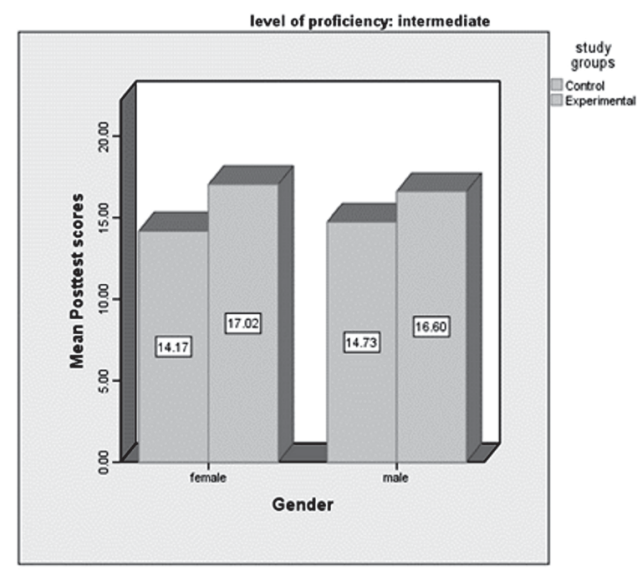

Figure 5. Experimental and Control Groups' Performance on Posttest of Speaking (Intermediate EFL Learners)

Table 7. Pairwise Comparisons ${ }^{A}$ for the Posttest Scores of Speaking (Intermediate Group)

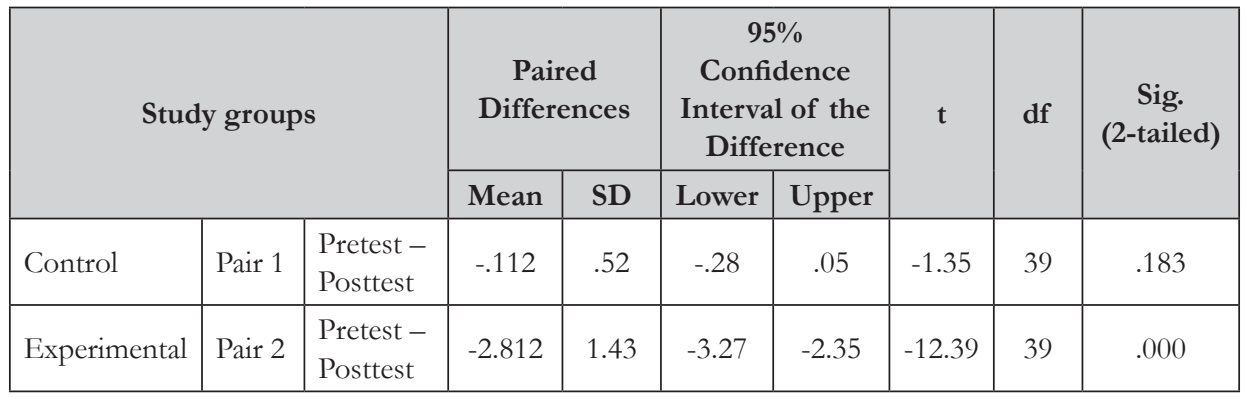

a. Based on estimated marginal means

**. The mean difference is significant at the .01 level.

the mean scores of the control group improved merely .112 points, the experimental group improved 2.812 points in post-test. The results of the comparisons for the beginner group are presented in Table 8.

Table 8 made pairwise comparisons between the control and experimental groups for the beginner language learners in their posttest of speaking. Similar to the intermediate groups, for the speaking test that was administered at the end of the study, the mean difference 
Table 8. Pairwise Comparisons ${ }^{A}$ for the Posttest Scores of Speaking (Beginner Group)

\begin{tabular}{|c|c|c|c|c|c|c|c|c|c|}
\hline \multirow{2}{*}{\multicolumn{3}{|c|}{ Study groups }} & \multicolumn{2}{|c|}{$\begin{array}{c}\text { Paired } \\
\text { Differences }\end{array}$} & \multicolumn{2}{|c|}{$\begin{array}{c}95 \% \\
\text { Confidence } \\
\text { Interval of the } \\
\text { Difference }\end{array}$} & \multirow[t]{2}{*}{$\mathbf{t}$} & \multirow[t]{2}{*}{ df } & \multirow[t]{2}{*}{$\begin{array}{c}\text { Sig. } \\
\text { (2-tailed) }\end{array}$} \\
\hline & & & Mean & SD & Lower & Upper & & & \\
\hline Control & $\begin{array}{c}\text { Pair } \\
1 \\
\end{array}$ & $\begin{array}{l}\text { Pretest - } \\
\text { Posttest }\end{array}$ & -.087 & .43 & -.22 & .05 & -1.26 & 39 & .213 \\
\hline Experimental & $\begin{array}{c}\text { Pair } \\
2\end{array}$ & $\begin{array}{l}\text { Pretest } \\
\text {-Posttest }\end{array}$ & -2.175 & 1.49 & -2.65 & -1.69 & -9.19 & 39 & .000 \\
\hline
\end{tabular}

between pre and posttests that were reported for the experimental group, was higher than that compared to the mean difference for the control (mean difference ${ }_{\text {control group }}=.087$; mean

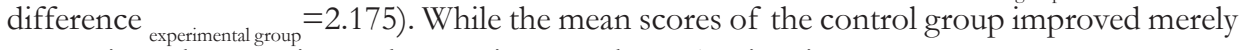
.087 points, the experimental group improved 2.175 points in post-test.

The comparison between the pre and posttests of the beginner and intermediate groups also revealed that, for the beginner participants, the distance between the means of the pre and posttest for the experimental groups was smaller than that for the difference between the means of the pre and posttest of the experimental groups at the intermediate level. In other words, the intermediate EFL learners' achievement in speaking after receiving awareness raising on speech acts was higher than the beginner group and made greater improvements within groups from pretest to posttest compared to beginners.

Thus, the results implied that the intermediate EFL learners' achievement in speaking after awareness raising on speech acts was not in line with the beginner learners' achievement in the corresponding group.

To provide an answer to the first research question, the results of the Univariate test were analyzed for the posttest of speaking for the beginner EFL learners in both the control and the experimental groups. The findings of the UNIANOVA showed that awareness raising on speech acts resulted in better speaking as compared to simply traditional teaching of speaking for Iranian beginner EFL learners. Therefore, the first null hypothesis was rejected implying that there was statistically a significant difference between the beginner EFL learners who received awareness raising on speech acts and those who received traditional instruction in terms of their L2 speaking ability.

To provide an answer to the second research question, the results of the Univariate test were analyzed for the posttest of speaking for the intermediate EFL learners in both the control and the experimental groups. The findings of the UNIANOVA revealed that Iranian 
intermediate EFL learners who enjoyed awareness raising on speech acts, performed better than those who simply experienced the traditional teaching of speaking in their speaking tests. Consequently, the second null hypothesis was rejected implying that there was statistically significant difference between the intermediate EFL learners who receive awareness raising on speech acts and those who receive traditional instruction in speaking classes in terms of their L2 speaking ability.

To provide an answer to the third research question, the results of the interaction effects of gender and types of treatment were employed for the posttest of speaking of the beginner EFL learners in the experimental groups. The findings showed that Iranian beginner male EFL learners who enjoyed awareness raising on speech acts did not perform statistically different from beginner female EFL learners in their speaking tests. Consequently, the third null hypothesis was supported implying that gender does not interact with awareness raising on speech acts in such a way as to produce a statistically significant effect on the beginner EFL learners' speaking ability.

To provide an answer to the fourth research question, the results of the interaction effects of gender and types of treatment were employed for the posttest of speaking of the intermediate EFL learners in the experimental groups. The findings showed that Iranian intermediate male EFL learners who enjoyed awareness raising on speech acts did not perform statistically differently from intermediate female EFL learners in their speaking tests. Consequently, the fourth null hypothesis was supported implying that gender does not interact with awareness raising on speech acts in such a way as to produce a statistically significant effect on the intermediate EFL learners' speaking ability.

\section{Discussion and Conclusions}

The present study intended to investigate empirically the possible effects of provision of salient information on speech acts on Iranian beginner and intermediate EFL learners' speaking ability. As it was shown in the previous section, awareness raising on speech acts resulted in a better speaking ability as compared to simply traditional teaching of speaking for Iranian intermediate and beginner EFL learners. Besides, intermediate EFL learners' achievement in speaking was not in line with the beginner EFL learners' achievement in the corresponding group. In other words, the intermediate EFL learners' achievement in speaking after receiving awareness raising on speech acts was slightly higher than the beginner learners' achievement. Finally, it was found that gender does not interact with awareness raising on speech acts in such a way as to produce a statistically significant effect on the beginner and intermediate EFL learners' speaking ability. So, the findings of this study support the research of Bardovi-Harlig (2001), who noted that pragmatics instruction results in developing the learners' competence in a foreign language setting. 
Kobra Ghayebi

Parisa Farrokh

Moreover, the outcomes of the present study are in line with the work of Ishihara (2007), who proved that speech act instruction has a positive effect on learners' competence and leads to appropriate language use. However, the results of this research are in contrast with the research conducted by Felix Brasdefer (2008), who believed that speech acts are highly complex and also highly sensitive to gender.

On the whole, the study revealed and emphasized that awareness raising on speech acts resulted in a better speaking ability as compared to the mere traditional teaching of speaking for Iranian intermediate and beginner EFL learners. Thus, one major pedagogical goal of this research is to help learners develop their competence of speech acts use by providing them with the chance of understanding and using them in a variety of contexts. Needless to say, pragmatic competence is a relevant aspect to pursue when learning another language.

The findings of this study can also be of interest to different groups such as curriculum planners, L2 specialists, EFL learners, and EFL teachers. The finding that the participants in the treatment groups in this study improved in speaking ability may encourage teachers and researchers in the ESL/EFL field to provide speech act strategies that students can benefit from. Additionally, teachers should feel confident that providing speech act strategies is effective and helps learners to improve their speaking ability.

Furthermore, the results of this study pertain to the significance of speech act strategies for teachers. In teacher education courses, the findings may be useful for training language teachers who are instructing English as a language in EFL contexts. By thinking about the findings of the current study in regard to the significance of speech acts, teachers can enhance the learners' speaking ability.

\section{References}

Al-Zubeiry, H. Y. (2013). Intercultural miscommunication in the production of communicative patterns by Arab EFL learners. International Journal of English Linguistics, 3(5), 69-77. https:// dx.doi.org/10.5539/ijel.v3n5p69

Bardovi-Harlig, M. (2001). A communicative approach to language proficiency assessment in a minority setting, in C. Rivera (Ed.), Communicative competence approaches to language proficiency assessment: Research and application (pp. 107-122). Multilingual Matters.

Cohen, A. D. (1996). Developing the ability to perform speech acts. Studies in Second Language Acquisition, 18(7), 253-267. https://doi.org/10.1017/S027226310001490X

Farahian, M., Rezaee, M., \& Gholami, A. (2012). Does direct instruction develop pragmatic competence? Teaching refusals to EFL learners of English. Journal of Language Teaching and Research, 3(4), 814-821. https://doi.org/10.4304/jltr.3.4.814-821 
Felix Brasdefer, J. C. (2008). Perceptions of refusals to invitations: Exploring the minds of foreign language learners. Language Awareness, 17(3), 195-211. https://doi.org/10.1080/ 09658410802146818

Genç, Z. S., \& Tekyıldız, O. (2009). Use of refusal strategies by Turkish EFL learners and native speakers of English in urban and rural areas. Asian EFL Journal, 11(3), 299-328.

Ishihara, N. (2007). Web-based curriculum for pragmatic instruction in Japanese as a foreign language: An explicit awareness raising approach. Language Awareness, 17(1), 43- 59. https://doi. org/10.2167/la398.0

Kasper, G., \& Dahl, M. (1991). Research methods in interlanguage pragmatics. Studies in Second Language Acquisition, 13(2), 215-247. https://doi.org/10.1017/S0272263100009955

Kasper, G. (2008). Data collection in pragmatics research. In H. Spencer-Oatey (Ed.), Culturally speaking: Culture, communication and politeness theory ( $2^{\text {nd }} \mathrm{Ed}$.) (pp.279-303). Continuum.

Morkus, N. (2014). Refusals in Egyptian Arabic and American English. Journal of Pragmatics, 70(4), 86-107. https://doi.org/10.1016/j.pragma.2014.06.001

Nguyen, M. T. T. (2011). Learning to communicate in a globalized world: To what extent do school textbooks facilitate the development of intercultural pragmatic competence? RELC Journal, 42(1), 17-30. https://doi.org/ 10.1177/0033688210390265

Rashidi, N., \& Ramezani, S. (2013). On the impact of the role-play technique on the development of FL learners' pragmatic competence before and after formal instruction. International Symposium on Challenges (ISLC) (pp. 183-196). Ege University. 